\title{
Legal Mechanisms for Digitalization of the Activities of Prosecution Authorities
}

\author{
Anna Churikova ${ }^{1, *}$, Nina Manova ${ }^{2}$, and Mikhail Lavnov ${ }^{2}$ \\ ${ }^{1}$ Povolzhsky Institute of Management, branch of the Russian Academy of National Economy and \\ Public Administration under the President of the Russian Federation, 410012 Saratov, Russia \\ ${ }^{2}$ Saratov State Law Academy,410056 Saratov, Russia
}

\begin{abstract}
Prosecution authorities in most countries act as guarantors of the legality and validity of criminal prosecution, thereby ensuring the social and economic well-being of the state and society. Outdated paper forms of interaction between prosecution authorities and other law enforcement agencies in criminal investigations overload the existing system and make it less effective. Using the main general scientific methods of cognition, the authors come to the conclusion that it is necessary to improve the legal regulation of the digitalization of the prosecution authorities. As a result of the study, three main tasks have been identified to which the digitalization of the activities of the prosecution authorities should be directed.
\end{abstract}

\section{Introduction}

Technological progress and the growth of mass availability of technologies have generated two main trends: 1) the growth of cybercrime, noted both by Russian [1, p. 423424] and foreign scientists [2, p. 486-489]; 2) heightened public interest in the course of investigation and consideration of criminal cases, giving rise to the need for transparency at all stages of criminal proceedings.

In this regard, scientists reasonably note the emergence of an urgent need for openness and transparency in the activities of law enforcement agencies, especially those carrying out and monitoring the implementation of criminal prosecution [3, p. 303; 4, p. 714-717; 5, p. ; 6, p. 86-87]. The prosecutor's office both in the Russian Federation and in most foreign countries, is the main body of state criminal prosecution. The legality and validity of the criminal prosecution carried out on behalf of the state is a key factor in the social and economic well-being of the state and society. In most states of the world, it is the prosecutor's office that ensures the legality, validity and impartiality of criminal prosecution [7]. Despite the fact that in Russia the prosecutor's office formally cannot initiate criminal cases itself, or give a binding order to initiate a criminal case, nevertheless, the solution of this issue directly depends on the prosecutor, because according to Art. 146 of the Criminal Procedure Code of the Russian Federation [8] both the bodies of inquiry and investigative bodies are obliged to send their decision to initiate a criminal case to the prosecutor, and the

*Corresponding author: a_tschurikova@bk.ru 
prosecutor has the right to cancel any decision to initiate a criminal case if it is considered illegal or unreasonable. The result of the investigation in Russia is the filing of an accusation against a specific person, which is also confirmed and sent to the court by the prosecutor. That is, in the Russian Federation, as well as in most other European countries, prosecutors ultimately decide whether a criminal investigation will be carried out and whether a criminal prosecution against a person before a court will be upheld. It is the prosecutor's office that actually acts as the guarantor of the impartiality, legality and validity of criminal prosecution. However, the activity of the prosecutor's office in the criminal process is still closed [9, p. 11-12], and interaction with other law enforcement agencies occurs in most cases on paper, which prevents the provision of an adequate level of control and coordination over the implementation of criminal prosecution by the bodies of inquiry and investigation.

In the Russian Federation, the prosecutor's office in most cases deals with a huge amount of paper documents, which negatively affects the effectiveness of the work of prosecutors, especially in criminal proceedings. The exchange of data between the prosecutor's office, the investigating bodies and the courts requires a considerable period of time, since criminal cases are sent in paper form. Given the distance in the Russian Federation, sending criminal cases, paper notices, decisions, etc. can take a long time. Furthermore, this can negatively affect the confidentiality of information, since in remote areas, the transfer is often carried out by mail. Serbia faced a similar problem. It was possible to get on the path of solving this issue by implementing EMC Documentum $\mathrm{xCP} 2$, a world-leading case management platform [10].

These circumstances cause an urgent need for a full digitalization of the activities of the prosecutor's office not only in the Russian Federation, but also in most countries of the world.

The introduction of digital technologies in the field of criminal justice in general and in the activities of the prosecutor, in particular, is one of the most discussed issues in science and practice. Some scientists see digitalization as the end of the traditional criminal process and believe that soon virtually any person who knows how to use the appropriate program will be able to investigate criminal cases [11, p. 136], others, on the contrary, believe that digitalization does not carry anything new, and it is impossible to talk about any significant technological breakthrough $[12$, p. 22-24]. We believe that the approach to the digitalization of criminal proceedings is more justified as a necessary need to improve the procedure for investigation and consideration of criminal cases, which can significantly facilitate the activities of courts and law enforcement agencies [13].

Of particular interest is the study of digital information platforms as a subject of legal regulation in the field of criminal proceedings, conducted by V.N. Grigoriev et al. [14]. Furthermore, the digitalization of prosecutorial supervision in Russia became a direct subject of research, for example, in the scientific paper by K. Tabolina and V. Tabolin [15, $16,17]$.

Despite this, the legal mechanism of digitalization of the activities of the prosecution authorities remains a controversial issue and requires relevant research.

As a key task of the study, it is proposed to establish the main directions for improving the legal mechanism for digitalizing the activities of the prosecution authorities in the criminal process, which would make it possible to fully realize all the advantages of scientific and technological progress, while maintaining and protecting the basic criminal procedural values, as well as the values of the legal state and civil society.

It seems that the vector of development of domestic criminal proceedings should be determined by the recognition of the prosecutor as the head of all procedural activities related to criminal prosecution. Only a comprehensive study of international standards for organizing the activities of the prosecutor's office and standards of justice, in conjunction 
with a comprehensive study of theoretical developments, will make it possible to form the main elements of the mechanism of the digital transformation of the domestic criminal process and the role of the prosecutor in the changing realities. As the main issues that reveal the stated problems, it seems necessary to establish the relationship between the existing model of the prosecutor's activity and the digital technologies introduced into the criminal process. The second most important task is to establish a correlation between digital technologies and the basic values that determine the structure of the entire criminal justice process. The solution to this problem should identify those changes that are only of a technical nature and do not affect the "foundation" of the criminal process, as well as determine the really significant aspects that affect the essence of all criminal procedural activities. In conclusion, the quality of the current model of the participation of the prosecutor in criminal proceedings should be determined and the main ways to improve it through the digitalization of the relevant activities should be identified.

\section{Methods}

This paper is devoted to the digital transformation of criminal justice from the standpoint of creating an effective legal model for the activities of prosecution authorities. At the fundamental level, using rich international experience, domestic theoretical developments in the field of constitutional, criminal procedural law, organizational foundations of the activities of the prosecution authorities, they undergo a deep understanding of the problem of introducing rapidly developing digital technologies into the fabric of the criminal process.

The tasks were solved using a complex of general scientific and specific scientific methods: deduction, analysis, methods of comparative jurisprudence and by analyzing Russian and foreign scientific literature, actual criminal cases investigated in the Russian Federation, as well as analyzing the current legislation and bylaws.

\section{Results and discussion}

The main regulatory document defining the field of digital technologies and digital transformation of society is the Strategy for the Development of the Information Society of the Russian Federation for 2017-2030 [18], which states that digital technologies have become part of modern management systems in all sectors of the economy, spheres of public administration, and national defense, state security and law enforcement. Moreover, if you pay attention to the Digital Economy of the Russian Federation Program (approved by order of the Government of the Russian Federation No. 1632-r dated 28.07.2017), it can be noted that the General Prosecutor's Office of the Russian Federation is one of the platforms for the introduction of digital technologies in modern Russia. By order of the Prosecutor General of the Russian Federation No. 627 dated 14.09.2017, the Concept of the digital transformation of the prosecutor's office of the Russian Federation until 2025 was approved. This concept determined the main goals, objectives, principles and directions in the field of introducing information (digital) technologies in the work of the prosecution authorities, as well as the mechanisms for its implementation and the expected results. As part of the implementation of this concept, it is planned to create a digital infrastructure characterized by increased security, the formation of conditions that allow a quick response to changes associated with the development of information technologies. Moreover, the implementation of the Concept presupposes the introduction of a single platform that provides a unified system of interdepartmental electronic interaction in order to accelerate and automate the relevant processes. 
Furthermore, the study of the legal mechanisms of digitalization of a certain kind of state activity seems impossible without studying the historical background. The scientific and technological revolution that happened in the XX century is perhaps the most significant in the entire history of human existence. However, legislative reactions to changing social relations remained quite restrained. In the field of criminal procedural science, such changes were assessed in the light of well-established principles and were not perceived as something fundamentally changing the entire doctrine of criminal proceedings. An exceptionally correct assessment of this phenomenon was given by Professor L.V. Golovko, who noted that it was about local optimization of the procedural form, which contributed to the development of the classical justice system, but did not pose any threat to it, including from the point of view of doctrinal principles [12, p. 19]. The position of Professor L.A. Voskobitova that only a balanced and careful approach to the implementation of digital technologies will allow not to harm, but to improve criminal proceedings, while maintaining the achieved level of guarantees of human rights, also seems justified [19, p. 102-103]. In this regard, it seems to us early to say that digital technologies are putting on the threshold of creating a new type of criminal justice.

The introduction of digital technologies into the criminal process can now be conditionally divided into a number of relatively independent areas. First, it is a rejection of the traditional form of a criminal case and the transfer of all proceedings to an electronic environment. As fairly noted by O.S. Kapinus, the prosecution authorities are assigned a key role in combating crime. It is the prosecutor who coordinates the activities of law enforcement agencies, ensures their effective interaction, which is directly related to the use of modern digital technologies [20, p. 6-7]. It seems that the transfer of criminal proceedings to a digital platform will allow prosecutors to qualitatively exercise their powers at a new level.

Second, digitalization of all spheres of public life has a significant, more positive impact on the process of investigation, crime detection and resolution of criminal cases on the merits. With all the significance of such digitalization, it should be recognized that they do not affect the basic values and foundations of criminal justice. Such changes do not affect the status of participants in the criminal process, do not diminish the importance of the figure of the investigator, prosecutor, judge, do not create a new system of principles and do not determine the new purpose of all criminal procedural activities. The third aspect to which attention should be paid is the realization of one of the fundamental rights of the individual in a democratic state: the right to access to justice. The methods of communication between the individual and the state are an extremely important problem in matters of digitalization of the activities of the prosecutor's office and all criminal proceedings in general.

The legal status of the prosecutor in the modern Russian state, his functional purpose, and the range of powers in the field of criminal proceedings clearly indicate that ensuring citizens' access to justice is the most important responsibility of the prosecution authorities. However, at the legislative level, the prosecutor, being the main participant in the criminal process, is not positioned as a subject responsible for the quality of the implementation of the mentioned right $[21$, p. 56].

Moreover, the closed nature of the legal system in the field of criminal proceedings, the lack of transparency in the investigation of criminal cases, often leads to violations of the rights and legitimate interests of persons involved in the sphere of criminal proceedings. Furthermore, these violations are committed not only by the preliminary investigation bodies, but also by the prosecutors themselves [6, p. 85-86].

This fact raises the need to improve the current legislation, taking into account both the needs for improving and facilitating the work of both the prosecutor's office itself, and the need of society and an individual for awareness. 


\section{Conclusions}

Thus, it seems that the creation of a full-fledged legal mechanism for digitalization of the activities of prosecution authorities should be aimed at solving the following main tasks:

1. ensuring the possibility of effective and simple interaction with other law enforcement agencies, coordination of their activities in the investigation of crimes and the implementation of criminal prosecution;

2. ensuring the transparency to the public about the progress of the investigation and the implementation of criminal prosecution in compliance with the balance of interests of the individual and ensuring the secrecy of confidential information;

3. effective interaction with the person against whom the criminal prosecution is being carried out, including effective information provision.

This requires the adoption of a regulatory legal act regulating the creation of a unified digital platform under the control of the prosecution authorities. Taking into account the leading and coordinating role of the prosecution authorities in the criminal process, it will also be necessary to amend the current Russian criminal procedural legislation aimed at defining the role of the prosecutor as the head of criminal prosecution.

\section{Acknowledgments}

The reported study was funded by RFBR, project number 20-011-00887 "Legal model of Prosecutor's activity as a basis of a strategy for reform of the criminal procedure".

\section{References}

1. A.V. Serebrennikova, Russian J. of Criminology, 14(3), 423 (2020)

2. S.G.A. Van de Weijer, R. Leukfeldt, W. Bernasco, European J. of Criminology, 16(4), 486 (2019)

3. A.M. Carlson, The need for transparency in the age of predictive sentencing algorithms, Iowa L. Rev., (2017) https://ilr.law.uiowa.edu/

4. P. Ricci, P. Pavone, Int. J. of Public Sector Management, 33(6/7), 713 (2020)

5. Stephanos Bibas, Transparency and Participation in Criminal Procedure, Scholarship at Penn Law, 81 (2006)

6. A.Yu. Churikova, S.A. Stepanov, Criminal Procedure, 5(185), 82 (2020)

7. Recommendation N R (2000) 19 of the Committee of Ministers of the Council of Europe "On the role of the prosecutor's office in the criminal justice system" (Together with the "Explanatory note", "Comments...") Council of Europe and Russia, 746 (2004)

8. Criminal Procedure Code of the Russian Federation No. 174-FZ dated 18.12.2001 (as amended on 27.10.2020)

9. E. Gonzalez, Criminal Justice, 34(3), 9 (2019)

10. From paperwork to digitalization: Public Prosecutor's Office. URL: https://comtradeintegration.com/en/resource/from-paperwork-to-digitalization-publicprosecutors-office/

11. A.S. Aleksandrov, The Problems of the Theory of Criminal Procedural Proof, Which must be Solved in Connection with the Transition to the Digital Age. Judicial Authority and Criminal Process, 2018, no. 2, pp. 130-139

12. L.V. Golovko, Bulletin of economic security, 1, 15 (2019) 
13. A. Cordella, F. Contini, Digital Technologies for Better Justice. April, 2020. 101 p. https://publications.iadb.org/publications/english/document/Digital-Technologies-forBetter-Justice-A-Toolkit-for-Action.pdf

14. V.N. Grigoryev, A.P. Sukhodolov, S.S. Ovanesyan, M.G. Spasennikova, V.V. Tyunkov, Russian J. of Criminology, 13(6), 873 (2019). DOI: 10.17150/25004255.2019.13(6).873-883.

15. K. Tabolina, V. Tabolin, 6th International Conference on Social, economic, and academic leadership (ICSEAL-6-2019), p. 376-381. https://download.atlantispress.com/article/125940960.pdf

16. H. Putzke, A.N. Tarbagaev, A.D. Nazarov, L.V. Maiorova, Russian J. of Criminology 12(3), 424 (2018). doi: 10.17150/2500-4255.2018.12(3)

17. S.N. Buday, M.V. Kolesov, Use of digital capabilities to improve the efficiency of control and supervision. Amazonia Investiga, 8(23), 734 (2019)

18. Decree of the President of the Russian Federation No. 203 "On the Strategy for the Development of the Information Society in the Russian Federation for 2017 - 2030" dated 09.05.2017. http://www.consultant.ru/document/cons_doc_LAW_216363/

19. L.A. Voskobitova, Lex russica (Russian law), 5(150), 91 (2019)

20. O.S. Kapinus, Bulletin of the Academy of the General Prosecutor's Office of the Russian Federation, 4(66), 5 (2018)

21. L.N. Maslennikova, K.A. Tabolina, Bulletin of the University of the Prosecutor's Office of the Russian Federation, 3(77), 51 (2020) 